\title{
Isabel Paraíso: \\ La métrica española en su contexto románico. Arco/Libros, Madrid, 2000.
}

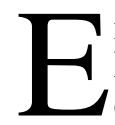

n la colección Perspectivas de la editorial Arco/Libros, Isabel Paraíso, Catedrática de Teoría de la Literatura de la Universidad de Valladolid, ha publicado La métrica española en su contexto románico. En este nuevo libro, que se suma a numerosas investigaciones de la autora en varios campos, entre ellos el de la métrica, se aborda fundamentalmente el estudio de la poesía española y de sus formas métricas con una orientación comparatista muy útil para comprender en su justa medida las cuestiones teóricas del verso en diferentes literaturas, con sus caracteres generales y específicos, así como los problemas y detalles de la evolución histórica. La métrica se divide en tres amplias partes. En la parte I, "Contexto de la métrica española” trata Isabel Paraíso en sucesivos capítulos de los aspectos básicos de métrica general, comunes a distintos sistemas de versificación, así como de la evolución en formas específicas de la versificación latina a la romance. En la parte II, la autora se centra en los "Constituyentes métricos de la poesía española": rima, acento, pausa, metro, estrofa y poema. En la parte III, "Los poemas españoles en su contexto románico”, estudia por extenso diferentes tipos poemáticos de carácter estrófico y no estrófico. Como es apreciable, se trata de un tratado de métrica española dirigido, como la propia autora indica en unas "Palabras previas", a los estudiantes de Universidad y a los profesores de Enseñanzas Medias, de ahí la presentación didáctica de los contenidos, con cuadros sinópticos, resúmenes, selección de la bibliografía determinada por las fuentes esenciales, etc. No obstante, La métrica española en su contexto románico es, además, un tratado sumamente útil también para los profesores de Universidad interesados en el campo teórico e histórico de la métrica, ya que Isabel Paraíso sabe aunar la claridad expositiva didáctica y la pulcritud y erudición que 
caracterizan su actividad investigadora. Así, se encuentran a lo largo del libro aportaciones teóricas y comentarios de carácter histórico sobre distintos aspectos, de interés para el investigador de la métrica, especialmente en lo que se refiere a la relación de la poesía española con otras lenguas y culturas.

Según explica Isabel Paraíso en el capítulo I, “Métrica general”, el estudio de la métrica es esencial para la poesía. No hay más que recordar que más de la mitad de nuestra literatura está escrita en verso, de ahí que la métrica sea parte fundamental de la Poética o Teoría de la literatura, de la Teoría del lenguaje poético, concretamente del lenguaje versificado. Éste habrá de ser abordado tanto desde un punto de vista sincrónico, que correspondería a una métrica sistemática, como desde un punto de vista diacrónico, del que se ocuparía la métrica histórica. Además, se puede estudiar el verso de una lengua particular -métrica general-o las similitudes y diferencias entre varias métricas nacionales -métrica comparada-. Partiendo de estas matizaciones, el manual de Isabel Paraíso es un estudio de la métrica española que si bien atiende, sobre todo, a la métrica sistemática de la lengua española no desatiende las otras tres perspectivas. Tras comentar las relaciones entre verso, poesía y prosa, Paraíso se ocupa del concepto fundamental de ritmo, entendido como repetición de uno o varios elementos lingüísticos que pueden cambiar a lo largo de la historia, de ahí los distintos sistemas versificatorios y la posible aparición de novedades métricas en una misma lengua. El soporte material del ritmo sería el verso, la unidad rítmica menor que se combina con otras unidades en una serie rítmica que en su unidad superior constituye el poema. Los elementos fundamentales del ritmo del verso español son el metro o número de sílabas, la distribución de los acentos, la rima, la posible existencia de las estrofas y las pausas. De los diferentes sistemas de versificación existentes, que Paraíso comenta ampliamente en su estudio, la versificación paralelística, la versificación cuantitativa, la versificación acentual, la versificación irregular -ametría y fluctuación- y la versificación silábica -o métrica-, esta última es precisamente la dominante en la poesía española, aunque es posible encontrar otros sistemas. En este sentido, por ejemplo, la versificación irregular primitiva, propia de los modos de versificar de la Romania entre los siglos IX y xII, y que se suele considerar como defectuosa e inculta por ser anterior a la regularización métrica, es tratada por Isabel Paraíso atendiendo a su raíz rítmica acentual, relacionada con la música, y, por tanto, sin ningún matiz peyorativo. En el capítulo 2 de esta primera 
parte, se estudian las formas autóctonas latinas, caso del saturnio y el versus quadratus y su adaptación y continuación en formas medievales, la poesía latina medieval, la métrica eclesiástica, en la que se trata también de la poesía litúrgica en prosa, y otras clases de poesía romance regidas por el número de palabras o de acentos, en que la influencia de la prosa rítmica, el canto y la poesía acentual germánica son especialmente destacados, además de la poesía en la que es determinante el número de sílabas de los versos, nuevas imitaciones clásicas y algunas innovaciones, como es, por ejemplo, el caso del verso goliárdico.

Respecto a los fundamentos de la poesía española, que se abordan en el capítulo 3, la rima es considerada como el componente más llamativo y que mejor identifica al verso ante la mayoría de los receptores. En este capítulo se establece una amplia tipología de la rima según el número de sonidos que la integran, el tipo prosódico de la palabra que la porta, la disposición en la estrofa o el poema, etc., y se atiende también a su origen histórico. Igualmente útil y completo resulta el siguiente capítulo dedicado al acento, aspecto que es esencial en el verso, y no sólo en los sistemas acentuales sino en aquellos otros sistemas basados en el número de sílabas. Se plantea, entre otras cuestiones, aquí el problema de la acentuación y desacentuación rítmicas. En el caso de dos sílabas tónicas seguidas, puede suceder que dos sílabas tónicas en contacto mantengan en la lectura sus acentos, de manera que ambos sean perceptibles (acentuación enfática), o bien que se anule uno de ellos en favor del otro (desacentuación rítmica secundaria). Estas dos soluciones no son consideradas por Isabel Paraíso como incompatibles, ya que dependerían en cada caso de la lectura del receptor. La consideración del acento en el verso lleva a la autora al estudio y clasificación de las cláusulas, que se considera en relación con el sistema musical de Tomás Navarro Tomás, en que se distinguen conceptos como la anacrusis y el período rítmico interior y de enlace. Especialmente interesante es el comentario sobre el efecto estilístico del ritmo según las cláusulas dominantes, que Paraíso ejemplifica certeramente con el poema titulado "Canción del jinete” de Federico García Lorca. Al estudio de la pausa y sus clases, la cuestión de la sinafía y de la compensación, se suma el problema del encabalgamiento y sus tipos y valores expresivos, dentro de los cuales destaca un caso especial que denomina contra-encabalgamiento abrupto, llamado en métrica francesa contre-rejet y que consiste en que un fragmento versal breve -inferior a la mitad del verso- está aislado por pausa interna en posición final de verso y enlaza con el verso siguiente. 
El elemento básico en la versificación española y en todas las lenguas románicas sería el metro, sobre el que se sustentan los demás ritmos versales de la poesía culta. A partir de esta idea básica, Paraíso estudia la diferencia entre versos simples y compuestos, versos de arte mayor y menor y poemas isométricos y heterométricos. Se ocupa de la medida de los versos según su terminación, relacionando la métrica española con el cómputo silábico de otras métricas europeas, y se refiere a distintos fenómenos que se dan en la pronunciación de las vocales en contacto, como la sinéresis y la sinalefa, dentro de la cual distingue la sinalefa métrica, en la que las vocales que se unen pertenecen a dos grupos fónicos contiguos, la diéresis y la dialefa, además de una serie de licencias métricas por las que se añade o suprime una sílaba: prótesis, epéntesis, paragoge, aféresis, síncopa y apócope. El capítulo 7 se centra ya en los metros hispánicos, desde las 2 hasta las 22 sílabas, que se estudian y ordenan según sean de arte menor o mayor y según su importancia en la tradición poética española. Dentro de los versos de arte menor es el octosílabo el más usado. Aparece ya en los poemas más primitivos y se sigue empleando hoy. Aunque el octosílabo trocaico tendría un importante precedente en el versus quadratus o tetrámetro trocaico cateléctico, no descarta Paraíso un primer desarrollo autóctono del octosílabo en España, además de en Provenza y Francia, en Italia o Portugal, en que es más frecuente el octosílabo polirrítmico. Este tipo de apreciaciones tipológicas, teóricas e históricas, con continuas alusiones al contexto románico, se extienden al estudio de otras clases de versos, como el heptasílabo o el hexasílabo. Tras tratar los versos de 5 a 2 sílabas como versos auxiliares sobre todo, pasa la profesora Paraíso al apartado de los versos de arte mayor simples, en los que el endecasílabo ocupa un lugar especial. Después de establecer una completa tipología del endecasílabo y de exponer sus raíces y momentos de mayor plenitud en el panorama europeo y en la historia métrica española, se abordan otros metros simples de arte menor, mucho menos usados, como los de 9, 10, 12, 13, 15, 16, 17 y 18 sílabas. De entre los metros de arte mayor compuestos es el alejandrino el más frecuente y de mayor importancia, del que se expone su origen y desarrollo histórico y sus tipos rítmicos. A propósito del alejandrino, Paraíso se refiere al verso tridecasílabo de carácter ternario, que los simbolistas y modernistas mezclarían en un mismo poema con el verso bimembre alejandrino. Entendido como trímetro, y a diferencia de otros autores que ven en él un verso alejandrino con encabalgamiento léxico entre hemistiquios o con terminación aguda - 
incremento acentual- de una sílaba átona a final de hemistiquio, la profesora Paraíso defiende que se trata de versos de 13 y no de 14 sílabas, aunque en algunos casos admite las dos interpretaciones: «entre las hojas / del día / que se derrumba» $(5+3+5)$ y «entre las hojas del / día que se derrumba» $(6+1=7+7)$. Como versos compuestos se estudian también variantes del dodecasílabo, entre ellos el verso de arte mayor de los siglos XIV y XV, así como el hexadecasílabo y el decasílabo compuesto, además de los metros de 17, 18, 19, 20 y 22 sílabas.

El siguiente capítulo de esta segunda parte se ocupa de la estrofa y sirve de planteamiento a un desarrollo mucho más amplio que se cumple en toda la tercera parte del libro. Es considerada la estrofa como conjunto de versos con una estructura métrica determinada y un sentido completo. Sus orígenes se remontarían a la poesía litúrgica y remitirían al canto. Si se considera la unidad superior, el poema, puede distinguirse entre poemas isoestróficos o poemas polimétricos -denominados en la métrica francesa como heteroestróficos-, es decir, poemas unitarios y poemas mixtos. Pero también es posible encontrar poemas no estróficos, como el romance. Dentro de los estróficos, se pueden hallar una o varias estrofas, es decir, poemas monoestróficos y poemas poliestróficos, estos últimos generalmente de carácter más culto. A su vez el poema poliestrófico puede ser cerrado -de estrofismo fijo, con un número de estrofas ya determinado previamente, frecuente en la época medieval- o abierto, de estrofismo libre, más numeroso. Paraíso parte de la clasificación de Antonio Quilis en la consideración de la estrofa y el poema y añade el concepto de poema poliestrófico cerrado. Una nueva distinción útil en esta densa tipología del poema es la que se refiere a los poemas poliestróficos para separarlos entre poemas enlazados o con estribillo y poemas sueltos.

En el último capítulo de esta segunda parte se aplican las anteriores consideraciones a la unidad superior del poema en relación también al género y a la época histórica. En las primeras manifestaciones poéticas románicas, la poesía épica es no estrófica, mientras que la poesía lírica usa formas monoestróficas o poliestróficas con estribillo. Después el estribillo se va dejando de usar, al independizarse el poema del baile y de la música y surgen los poemas poliestróficos cerrados y abiertos. Si las primeras estrofas de la literatura románica son isométricas y de escaso número de versos, después -siglos XII y XIII- se aumenta el número de versos por estrofa y se introduce la heterometría. A partir de estas distinciones se enumeran los poemas españoles no estróficos y se clasifican los poemas estróficos españoles 
-monoestróficos y poliestróficos sueltos- según el número de sus versos, desde el mote -1 verso-hasta la décimotercera -13 versos-, teniendo en cuenta los criterios de si son versos de arte mayor o menor y si son heterométricos o isométricos. También se enumeran los poemas mixtos o heteroestróficos, los poemas estróficos con estribillo y los poemas poliestróficos cerrados o formas fijas. A esta extensa y completa clasificación se añade otra basada en la cronología de los poemas españoles: Edad Media, Renacimiento y Siglo de Oro, Ilustración y Romanticismo, Modernismo y siglo xx.

El desarrollo de los conceptos teóricos anteriores se produce en la tercera parte del libro, la más amplia de todas y, en nuestra opinión, la más interesante y densa. Comienza la autora con los poemas no estróficos, tratados desde un punto de vista histórico y teórico para los que se da cuenta de las posibles variaciones y modificaciones la serie o tirada, el romance, los versos sueltos o formas métricas sin rima, las imitaciones del hexámetro y el pentámetro, el madrigal, la silva y sus clases, la casida y el verso libre, al cual se le dedica, por su complejidad e importancia en el siglo xx, el siguiente capítulo. En éste la profesora Paraíso recoge con algunas matizaciones fundamentalmente terminológicas la clasificación y caracterización del versolibrismo de su trabajo ya clásico en este ámbito titulado El verso libre hispánico. Orígenes y corrientes (Gredos, Madrid, 1985). Establece las fuentes versolibristas y las principales corrientes y formas, destacando la tradicionalidad del verso libre hispánico. La tipología del verso libre se dividiría en dos grandes apartados que corresponden a las variantes versolibristas basadas en los ritmos fónicos y a las basadas en los ritmos semánticos. Entre las primeras modalidades se hallan las siguientes: verso de cláusulas libre, verso métrico libre, verso rimado libre y verso libre de base tradicional, en que se incluyen la silva libre, el verso fluctuante libre, el verso estrófico libre y la canción libre. Entre las segundas, de ritmo semántico, se mencionan el verso paralelístico menor y mayor, con el versículo y el versículo mayor, ya cercano al poema en prosa, y el verso de imágenes acumuladas o yuxtapuestas, el más vanguardista de todos.

Los siguientes capítulos tratan ya de los poemas estróficos según el esquema previamente establecido de poemas monoestróficos y poliestróficos, sueltos y abiertos, poliestróficos enlazados y abiertos, poliestróficos cerrados sueltos o enlazados. Se atiende en la exposición a dos criterios: primero, el sistemático, según el número de versos integrados en cada estrofa; segundo, el histórico, según el orden 
cronólogico de aparición. Se repasa así un gran número de formas populares y cultas, procedentes de diversas culturas y pertenecientes a distintas épocas, para las cuales se ofrece un marco histórico preciso en que se consideran la evolución de cada forma y sus posibles variantes. La consideración de estas formas poemáticas permite también acceder a formas afines de otras métricas que explican y aclaran la conformación de las estrofas hispánicas. A este exhaustivo recorrido por las formas poéticas hispánicas se suma en el capítulo 16 el estudio de los poemas polimétricos o heteroestróficos y la interesante y sugestiva relación que se establece entre formas métricas y géneros del apéndice final, que Paraíso ejemplifica con la cantiga de loor y la oda, haciendo ver la necesidad de evitar las denominaciones métricas dentro de los géneros y las denominaciones de géneros dentro de las formas métricas. Se trata, en definitiva, de un complejo y denso recorrido teórico e histórico de la métrica hispánica, hecho con rigor y con un claro afán de exhaustividad, que se inserta, como justamente indica el título, en los estudios de carácter comparativo tan necesarios en la comprensión de la literatura.

María Victoria Utrera TORREMOCHA 